\title{
Multivariate characterization of morphological traits in West African cattle sires
}

\author{
Amadou Traoré ${ }^{1}$, Delphin O. Koudandé ${ }^{2}$, Iván Fernández ${ }^{3}$, Albert Soudrée Isabel Álvarez $^{3}$, \\ Siaka Diarra ${ }^{5}$, Fousseyni Diarra ${ }^{5}$, Adama Kaboré ${ }^{1}$, Moumouni Sanou ${ }^{1}$, Hamidou H. Tamboura ${ }^{1}$, and \\ Félix Goyache ${ }^{3}$ \\ ${ }^{1}$ INERA, 04 BP 8645 Ouagadougou 04, Burkina Faso \\ ${ }^{2}$ INRAB Benin, 01 BP 884 RP Cotonou, Benin \\ ${ }^{3}$ SERIDA-Deva, Camino de Rioseco 1225, 33394 Deva-Gijón, Asturias, Spain \\ ${ }^{4}$ Université de Koudougou, BP 376 Koudougou, Burkina Faso \\ ${ }^{5}$ IPR-IFRA Bamako (Mali), BP 06 Koulikoro, Bamako, Mali \\ Correspondence to: Félix Goyache (fgoyache@ serida.org)
}

Received: 11 May 2016 - Accepted: 7 July 2016 - Published: 14 July 2016

\begin{abstract}
A total of 183 adult sires belonging to nine West African cattle breeds sampled in 67 villages of Mali, Burkina Faso and Benin were assessed for 16 body measurements and 18 qualitative traits. Within type of cattle (zebu, sanga or taurine), the different breeds analysed showed large differences in body measurements. In general, taurine breeds had lower average values than the zebu breeds while sanga cattle tended to have intermediate values. Principal component analysis identified three factors characterising body measurements. Factor 1 summarised the information provided by those traits characterising the size of the individuals and explained $59.0 \%$ of the variability. Factor 2 tended to gather information characterising the body width and explained $8.0 \%$ of the variation. Less representative, Factor 3 (6.6\% of the variability) had no clear interpretation. Qualitative traits did not allow to distinguish among either cattle groups or breeds. Two Correspondence Analysis Dimensions computed on qualitative traits (explaining 26.2 and $15.5 \%$ of the variability, respectively) did not allow to differentiate between zebu, sanga or taurine cattle breeds. Our results confirm that, in the framework of a general appearance, body measurements are the main criteria for differentiating West African cattle breeds. Furthermore, the current research has not allowed to identify breeding preferences on qualitative type traits in West African cattle sires. Therefore, homogenisation of the appearance of individuals within cattle breed is not expected.
\end{abstract}

\section{Introduction}

Morphological characterisation of animal populations is usually carried out within sex to avoid bias due to sexual dimorphism. In livestock, such studies are mainly carried out on females due to their larger numbers (Bene et al., 2007; Ndumu et al., 2008; Traoré et al., 2008a, b). We have recently assessed variation in body measurements and qualitative type traits in a total of 1015 adult cows belonging to nine West African cattle breeds to ascertain the existence of geographical patterns of morphological variation (Traoré et al., 2015). However, although information on the sire side is important to the characterisation of breeding preferences, morphological characterisation of West African sires is still lacking.
Even though breeds are usually considered the operation units for the assessment of livestock diversity, definition of native African cattle further needs to consider other criteria such as areas of spreading or cattle type (Soudré, 2011). Actually, West African cattle can be classified into two main groups: (a) humped zebu animals mainly spread over the Sahel (roughly above $13^{\circ} \mathrm{N}$ latitude), the agricultural zone between the Sahara and the coastal rain forests; and (b) humpless taurine populations, spread on a tropical SudanoGuinean area (southern $11^{\circ} \mathrm{N}$ latitude). However, due to the existence of strong gene flow among populations, there exist various sanga cattle breeds assumed to result from ancient 
Table 1. Description of sampling. The following information is given per breed: type of cattle into which the breed is classified and countries in which the individuals of a given breed were sampled. Number of cattle $(N)$, provinces and villages involved are provided as well.

\begin{tabular}{lllrrr}
\hline Breed & Type & Country & $N$ & Provinces & Villages \\
\hline 1. Zebu Azawak & West African zebu & Burkina Faso & 8 & 2 & 4 \\
2. Zebu Mbororo & West African zebu & Burkina Faso & 14 & 1 & 5 \\
3. Zebu Peul & West African zebu & Burkina Faso & 24 & 11 & 13 \\
& & Benin & 17 & 3 & 14 \\
4. Borgou & sanga & Benin & 5 & 4 & 4 \\
5. Gourounsi & sanga & Burkina Faso & 49 & 2 & 4 \\
6. N'Dama & West African taurine & Mali & 9 & 2 & 3 \\
7. Lagunaire & West African taurine & Benin & 22 & 7 & 8 \\
8. Lobi & West African taurine & Burkina Faso & 24 & 1 & 9 \\
9. Somba & West African taurine & Benin & 11 & 10 & 10 \\
\hline Totals & & & 183 & $28^{*}$ & $67^{*}$ \\
\hline
\end{tabular}

*Individuals belonging to different breeds could have been sampled in the same province or village.

taurine $\times$ zebu crosses mainly spread on a transitional semiarid agroecological Sudan-Sahel area (Álvarez et al., 2014).

The aim of the current research was to assess the variation on phenotypic traits among West African cattle sires and their consistency among cattle types. Assessment was carried out at both the quantitative and qualitative levels using multifactorial analyses that have been proved to be suitable in assessing the variation within a population and to discriminate different population types when all measured morphological variables are considered simultaneously.

\section{Materials and methods}

\subsection{Data and sampling}

Following the same methods described in Traoré et al. (2015), 183 sires (age ranging from 3 to 13 years old) belonging to 9 different cattle breeds of Mali, Burkina Faso and Benin were assessed for 16 body measurements and 18 qualitative traits (see Table 1 for a detailed description of sampling). Roughly $34 \%$ of the individuals (63 sires belonging to the Zebu Azawak, Zebu Mbororo and Zebu Peul breeds) were classified into the West African zebu (Bos indicus) cattle type, $36 \%$ (66 individuals belonging to the N'Dama, Lagunaire, Lobi and Somba breeds) were assigned to the West African taurine (B. taurus) cattle type and the remaining 54 sires (belonging to the Borgou and Gourounsi cattle breeds) were classified as sanga cattle type which is expected to result from ancient $B$. indicus $\times B$. taurus crosses.

Body measurements (Table 2) and qualitative traits (Table 3) were assessed following the FAO (2011) guidelines to phenotypic characterization of animal genetic resources. Age of the individuals was approached examining dentition. Body measurements were carried out, with the animals standing stationary on a flat floor, using a Lydthin stick, a tape measure and a Vernier caliper. The qualitative traits listed in Ta- ble 3 were scored with the same within-trait levels, codes and definitions used in Traoré et al. (2015). No ethics statement was required for data collection. Body measurements and trait scores were obtained from different technicians visiting farms with the permission of the owners. Animals were managed by the owners.

\subsection{Statistical analyses}

Body traits were analysed using PROC GLM of the SAS/STAT ${ }^{\mathrm{TM}}$ package (SAS Institute Inc., Cary, NC) via fitting the following linear model: $Y_{i j k l}=\operatorname{Type}_{i}+\operatorname{Breed}_{(i) j}+\operatorname{Age}_{(j) k}+\varepsilon_{i j k l}$, where $Y_{i j k l}$ is the body trait value, Type ${ }_{i}$ is the type of cattle with three levels ( $i=1 \ldots .3$; zebu, sanga and taurine), $\operatorname{Breed}_{(i) j}$ is the effect of the breed with nine levels $(j=1 \ldots 9$; see Table 1$)$ nested to type of cattle, and $\operatorname{Age}_{(i) k}$ is the effect of the age of the individual with four levels $(k=1 \ldots 4$; three ( 37 sires), four (63 sires), 5 to 10 (70 sires) and $>10$ (13 sires) years old) nested to type of cattle and $\varepsilon_{i j k l}$ the error associated to the record (as a random variable). Least square means and their corresponding standard errors were obtained for each level of both the type of cattle and the breed effects. Body measurements were further analysed via principal component analysis (PCA), using the PROC FACTOR of SAS/STAT ${ }^{\mathrm{TM}}$. The number of independent traits accounting for most of the phenotypic variation in body measurements was determined using the between-traits correlation matrix to ensure that the same weight was assigned to the variables in spite of their own variance. Only factors with eigenvalue $>1$ were retained. Original factors were rotated using VARIMAX criterion to ensure that the retained components were less correlated than the original traits.

Frequencies of each level of the qualitative traits analysed were computed using the PROC FREQ of SAS/STAT ${ }^{\mathrm{TM}}$. Statistical significance of the differences in computed fre- 


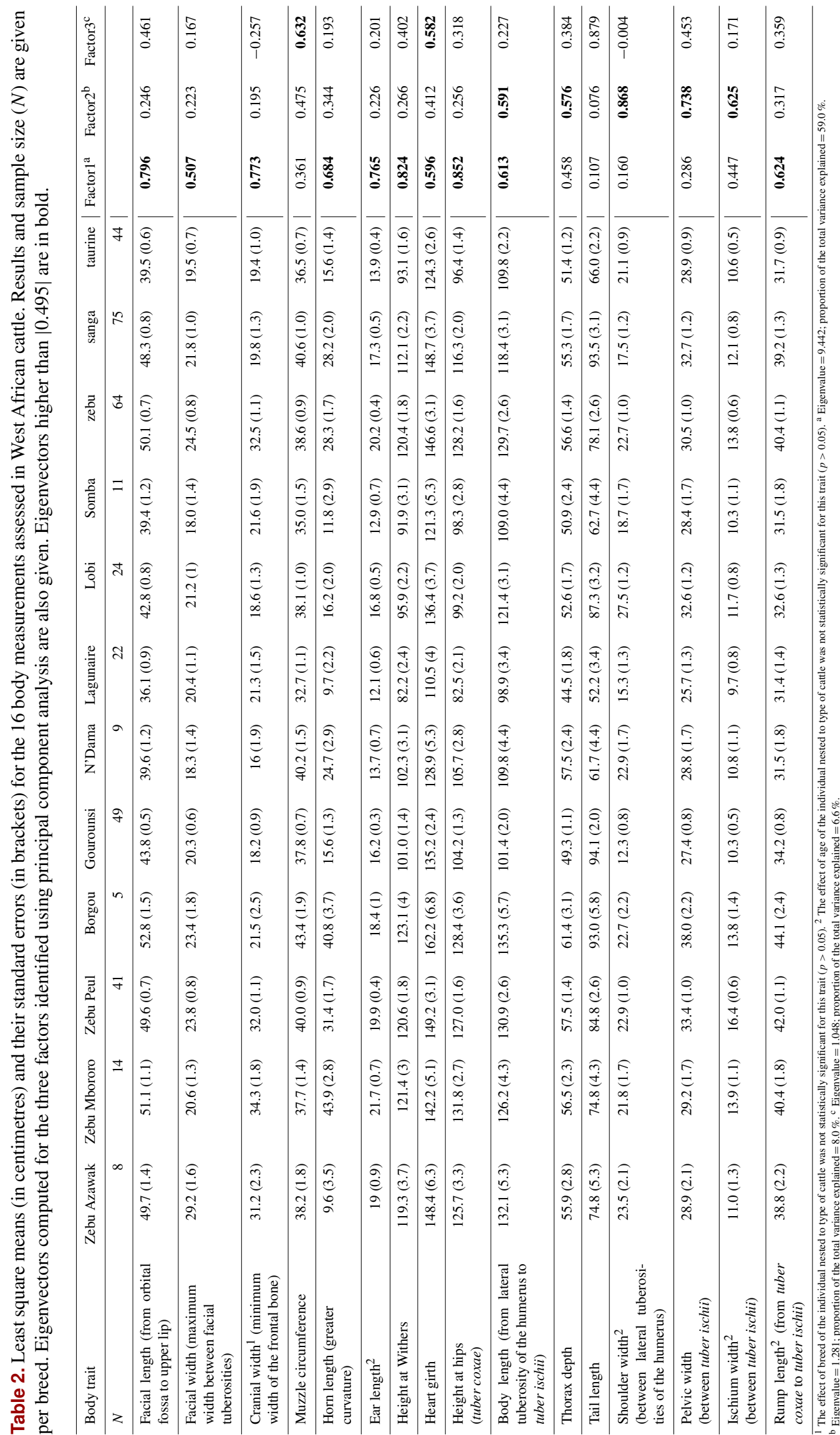




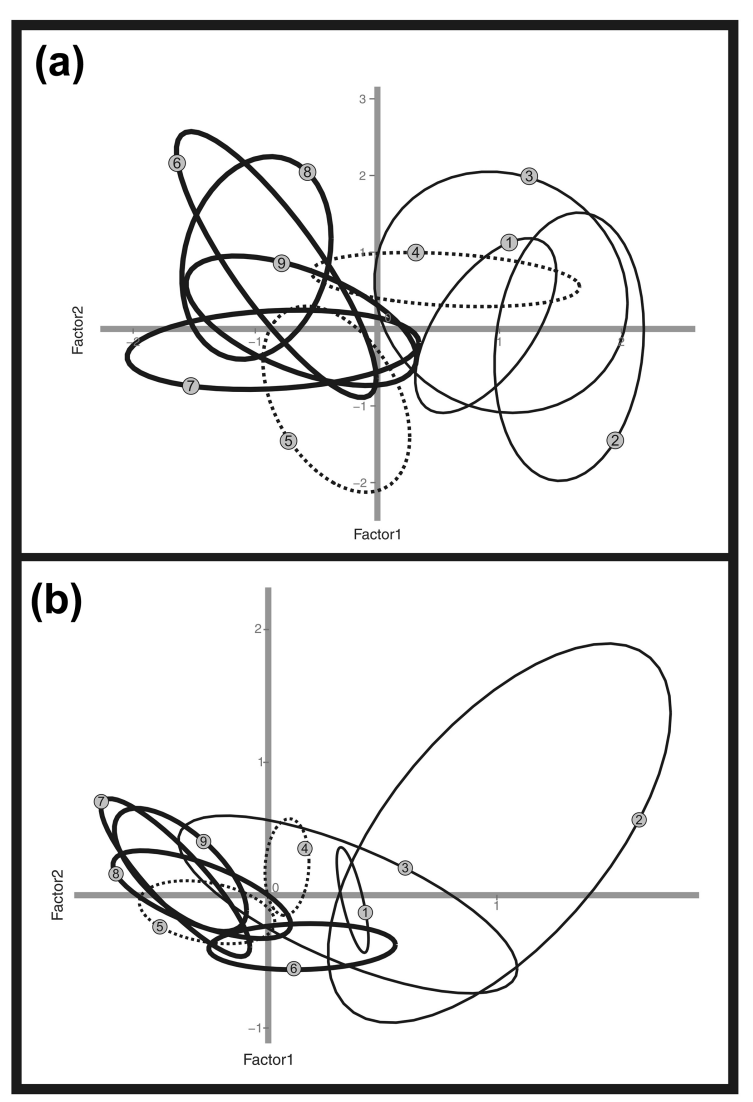

Figure 1. Contour plots showing the $75 \%$ confidence region of the relationships among the analysed individuals per breed. (a) shows the information provided by the principal component analysis carried out on body measurements: Factor 1, on the $x$ axis explained $59.0 \%$ of the total variance while Factor 2, on the $y$ axis explained $8.0 \%$ of the total variance. (b) shows the information provided by the correspondence analysis carried out on qualitative traits: dimension 1, on the $x$ axis explained $26.2 \%$ of the total variance while dimension 2, on the $y$ axis explained $15.5 \%$ of the total variance. Thin-line contours correspond to zebu breeds; dotted-line contours correspond to sanga breeds; and thick-line contours correspond to taurine breeds. Numbers on contours are consistent with those listed in Table 1 and mean the following: 1: Zebu Azawak; 2: Zebu Mbororo; 3: Zebu Peul; 4: Borgou; 5: Gourounsi; 6: N'Dama; 7: Lagunaire; 8: Lobi; and 9: Somba.

quencies at the breed levels was assessed via Chi-squared Mantel-Haenszel test. Relationships between qualitative traits were assessed via correspondence analysis using the PROC CORRESP of SAS/STAT ${ }^{\mathrm{TM}}$. Two canonical dimensions and their eigenvectors were computed to account for association between the levels of the traits scored.

Eigenvectors computed for each individual via PCA and correspondence analyses were used to construct contour plots illustrating $75 \%$ confidence region of the relationships among individuals using the library ggplot 2 of $\mathrm{R}$ (http: //CRAN.R-project.org/).

\section{Results}

Least square means estimated for each body measurement analysed are given in Table 2 per type of cattle and breed. Both the effect of type of cattle and the effect of the breed of the individual, nested to type of cattle, were observed to have a significant influence on data $(p<0.05)$ except for cranial width. Moreover, the age of the individual within type of cattle had a significant influence on data except for four traits (Table 2). Except for heart girth and pelvic width, zebu cattle had higher mean values than sanga and taurine cattle. In turn, taurine cattle had the smaller mean values. Least square means estimated for traits such as height at hips, body length or rump length were $31.8,19.9$ and $8.7 \mathrm{~cm}$ higher in zebu than in taurine cattle type. These differences were lower between zebu and sanga cattle type $(11.9,11.3$ and $1.2 \mathrm{~cm}$, respectively; see Table 2).

Observed frequencies (in percentage) for each level of the qualitative traits scored are given in Table 3 per breed and type of cattle. Chi-squared Mantel-Haenszel test informed that no statistically significant variation among breeds could be assessed for nine out of the 18 traits assessed. This happened in major traits such as Horn Shape and Coat Colour Pattern, suggesting that no clear selection for qualitative traits exist in West African cattle sires. Furthermore, major traits distinguishing between zebu and taurine cattle such as convex cephalic profile or presence or absence of hump had a limited ability to classify different cattle types: most zebu and all sanga and taurine individuals assessed had straight cephalic profile and most sanga sires were humpless.

Three factors, explaining $73.6 \%$ of the observed variability for body measurements were identified via PCA (Table 2). Factor $1(59.0 \%$ of the variance) summarised the information provided by those traits characterising the size of the individuals while Factor $2(8.0 \%)$ tended to gather information characterising the width of the individuals. Factor 3 (which explained $6.6 \%$ of the variance only) had no clear interpretation.

The two dimensions identified using correspondence analysis explained 26.2 and $15.5 \%$, respectively, of the observed variability for qualitative traits. Consistently with the small proportion of the total variability explained, the eigenvalues computed for the two correspondence dimensions retained (Table 3) informed that no clear differentiation existed among levels of the qualitative traits.

Figure 1 summarises, per cattle breed, the solutions provided by both the PCA and the correspondence analysis at the individual level. At the body measurements level (Fig. 1a) zebu and taurine cattle breeds could be distinguished on the $x$ axis, with the two sanga cattle breeds showing intermediate locations. No between cattle breeds differentiation could be assessed via correspondence analysis information (Fig. 1b): the $75 \%$ confidence regions computed for each breed were clearly intermingled. 


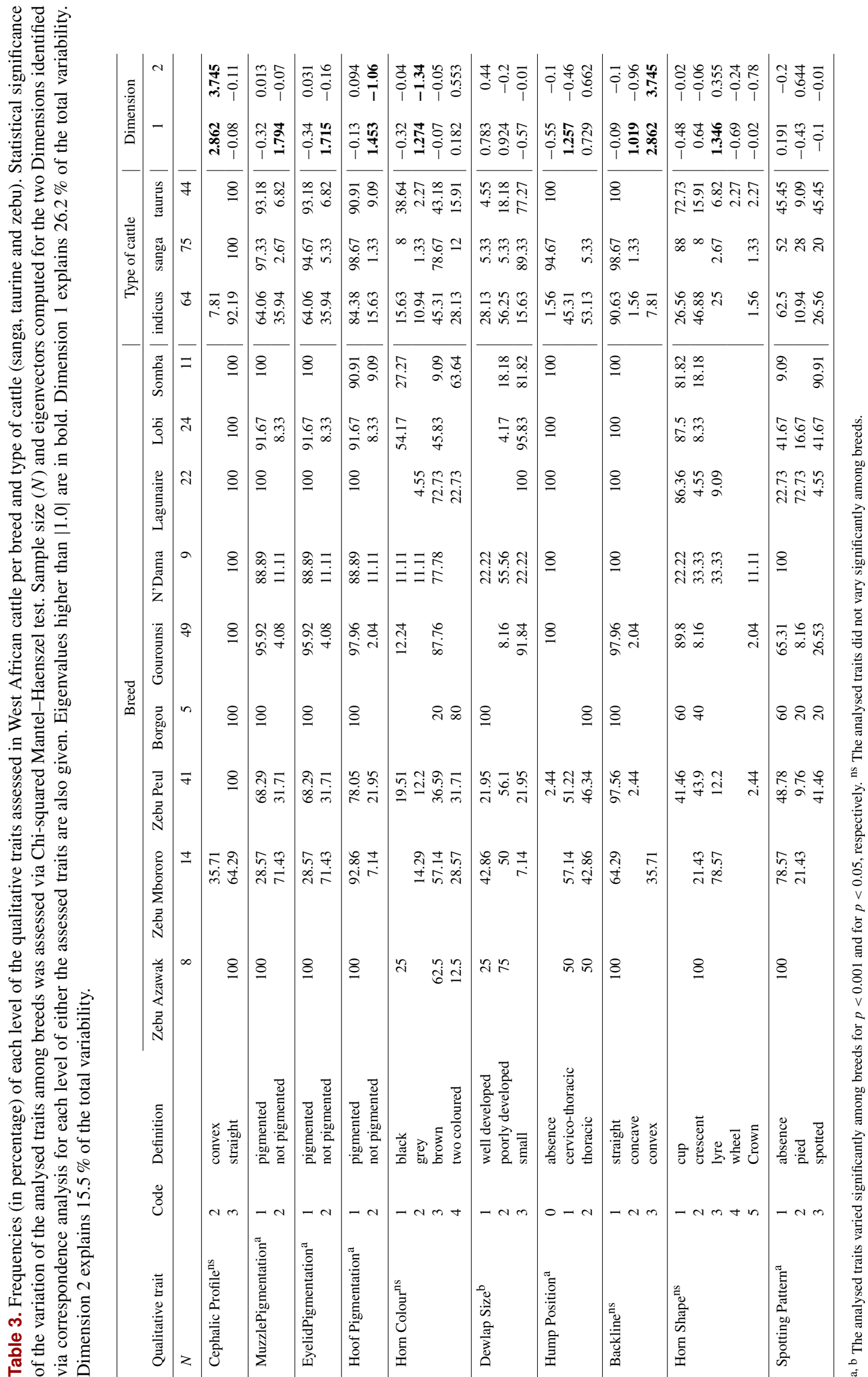




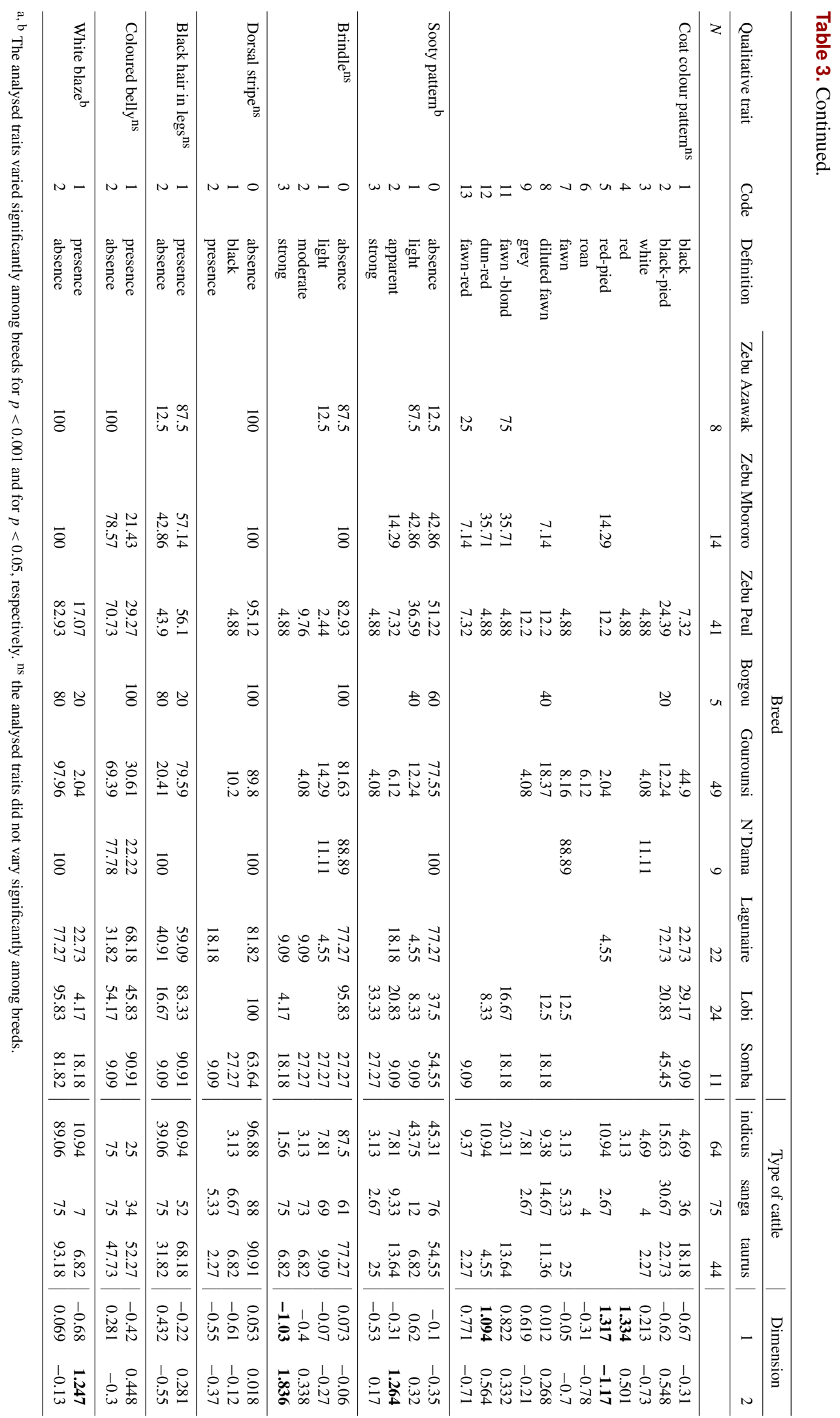




\section{Discussion}

Studies aiming at morphological assessment in cattle are relatively scant in cattle and mainly performed on adult females (Mwacharo et al., 2006; Bene et al., 2007; Ndumu et al., 2008). Although information on body measurements in White Fulani cattle (related with Zebu Peul) exists (Yakubu et al., 2009), mean values computed for the same body traits cannot be straightforwardly compared with our study due to differences in sampling strategies: a significant part of the individuals sampled by Yakubu et al. (2009) were less than 2.5 years old and, therefore, were probably still growing.

The current analysis highlights the importance of body measurements to differentiate among cattle groups and breeds in West Africa (Table 2). Differences in body shape between the main cattle types analysed in the current study (taurine and zebu) are due to major differences in origin (independent domestication events; Chen et al., 2010; PérezPardal et al., 2010a, b), but also due to breeding differences. West African humped zebu cattle are always larger and are bred in the northern arid Sahel while native West African taurine cattle are small sized (and even dwarf; see mean values for Lagounaire cattle in Table 2) and bred in the humid southern Soudano-Guinean agroecological area. Such differences among types of livestock and agroecological areas have been previously reported in goat and sheep (Álvarez et al., 2009; Traoré et al., 2008a, b, 2009, 2012).

Our results also suggest that body measurements are important to classify cattle into the sanga type. Even though the two sanga populations assessed here had noticeably different mean values for some body traits (e.g. body length or height at hips; see Table 2), taking all traits as a whole sanga cattle tended to be located in intermediate positions between zebu and taurine West African cattle (Fig. 1a). In any case, the current research confirms that qualitative traits have not much importance in the definition of either cattle breeds or cattle groups (Fig. 1b). Clearly, definition of cattle breeds in West Africa is not consistent with that assumed in Europe, in which qualitative traits are of particular importance for the inclusion of individuals in herd books. On the contrary, major qualitative traits such as coat colour and horn shape show large variability within West African cattle breeds and finding a particular feature in a given qualitative trait is more likely to be due to local preferences of the stock keepers rather than the classification of an individual into a given breed (Desta et al., 2011; Traoré et al., 2015).

Variation for both body measurements and qualitative type traits assessed in the current study resembles that previously reported for female West African cattle by Traoré et al. (2015). While those authors found significant differences among breeds for most body measurements, body measurements in cows mainly reflected between cattle-type differences. Furthermore, even though qualitative traits showed a larger variation in cows (e.g. $34.1 \%$ of sanga cows were humped; see Table 3 of the aforementioned paper), such traits had a limited ability to differentiate among types of cattle or breeds at the female level (Traoré et al., 2015). Overall, regarding morphology West African sires can be considered a random sample of the West African cattle population.

In summary, the current research has not identified breeding preferences on type traits in West African cattle sires. Therefore, homogenisation of the appearance of individuals within cattle breed is not expected in the breeding scenario of West Africa in which no selection programmes exist and unsupervised matings are the rule.

Acknowledgements. This paper was partially funded by grants from CORAF/WECARD-World Bank no. 03/GRN/16 and from MICIN-FEDER No. AGL2011-27585. IA, IF and FG are supported by grant FICYT GRUPIN14-113. The authors declare no conflict of interests.

Edited by: S. Maak

Reviewed by: J. Jordana and one anonymous referee

\section{References}

Álvarez, I., Traoré, A., Tambourá, H. H., Kaboré, A., Royo, L. J., Fernández, I., Ouédraogo-Sanou, G., Sawadogo, L., and Goyache, F.: Microsatellite analysis characterizes Burkina Faso as a genetic contact zone between Sahelian and Djallonké sheep, Animal Biotechnology, 20, 47-57, doi:10.1080/10495390902786926, 2009.

Álvarez, I., Traoré, A., Fernández, I., Lecomte, T., Soudré, A., Kaboré, A., Tamboura, H. H., and Goyache, F.: Assessing introgression of Sahelian zebu genes into native Bos taurus breeds in Burkina Faso, Mol. Biol. Rep., 41, 3745-3754, doi:10.1007/s11033-014-3239-x, 2014.

Bene, S., Nagy, B., Nagy, I., Kiss, B., Polgár, J. P., and Szabó, F.: Comparison of body measurements of beef cows of different breeds, Arch. Tierz. Dummerstorf, 50, 363-373, 2007.

Chen, S., Lin, B.-Z., Baig, M., Mitra, B., Lopes, R. J., Tarroso, P., Santos, A. M., Magee, D. A., Azevedo, M., Sasazaki, S., Ostrowski, S., Mahgoub, O., Chaudhuri, T. K., Zhang, Y.-P., Royo, L. J., Goyache, F., Luikart, G., Boivin, N., Fuller, D. Q., Mannen, H., Bradley, D. G., and Beja-Pereira, A.: Zebu cattle are an exclusive legacy of the South Asia Neolithic. Mol. Biol. Evol., 27, $1-6,2010$.

Desta, T. T., Ayalew, W., and Hedge, B. P.: Breed and trait preferences of Sheko cattle keeper in southern Ethiopia, Trop. Anim. Health Prod., 43, 851-856, doi:10.1007/s11250-010-9772-2, 2011.

FAO: Guidelines to Phenotypic characterization of Animal Genetic Resources, Food and Agriculture Organization of the United Nations (FAO), Rome, Italy, 2011.

Mwacharo, J. M., Okeyo, A. M., Kamande, G. K., and Rege, J. E. O.: The small East African shorthorn zebu cows in Kenya - I: Linear body measurements, Trop. Anim. Health Prod., 38, 6574, doi:10.1007/s11250-006-4266-y, 2006.

Ndumu, D. B., Baumung, R., Hanotte, O., Würzinger, M., Okeyo, M. A., Jianlin, H., Ibogo, H. K., and Sölkner, J.: Genetic and morphological characterization of the Ankole Longhorn cattle in 
the African Great Lakes region, Genet. Sel. Evol., 40, 467-490, doi:10.1186/1297-9686-40-5-467, 2008.

Pérez-Pardal, L., Royo, L. J., Beja-Pereira, A., Chen, S., Cantet, R. J. C., Traoré, A., Curik, I., Sölkner, J., Bozzi, R., Fernández, I., Álvarez, I., Gutiérrez, J. P., Gómez, E., Ponce de Leon, F. A., and Goyache, F.: Multiple paternal origins of domestic cattle revealed by Y-specific interspersed multilocus microsatellites, Heredity, 105, 511-519, doi:10.1038/hdy.2010.30, 2010a.

Pérez-Pardal, L., Royo, L. J., Beja-Pereira, A., Curik, I., Traoré, A., Fernández, I., Sölkner, J., Alonso, J., Álvarez, I., Bozzi, R., Chen, S., Ponce de León, F. A., and Goyache, F: Y-specific microsatellites reveal an African subfamily in taurine (Bos taurus) cattle, Anim. Genet., 41, 232-241, doi:10.1111/j.13652052.2009.01982.x, 2010b.

Soudré A.: Trypanosomosis, genetic diversity and admixture in cattle breeds of Burkina Faso, Doctoral thesis, University of natural resources and life sciences, Vienna, Austria, 107 pp., 2011.

Traoré, A., Tamboura, H. H., Kabore, A., Royo, L. J., Fernández, I., Álvarez, I., Sangare, M., Bouchel, D., Poivey, J. P., Francois, D., Toguyeni, A., Sawadogo, L., and Goyache, F.: Multivariate characterization of morphological traits in Burkina Faso sheep, Small Rum. Res., 80, 62-67, doi:10.1016/j.smallrumres.2008.09.011, 2008a.

Traoré, A., Tamboura, H. H., Kabore, A., Royo, L. J., Fernández, I., Álvarez, I., Sangare, M., Bouchel, D., Poivey, J. P., Sawadogo, L., and Goyache, F.: Multivariate analyses on morphological traits of goats in Burkina Faso, Archiv. Anim. Breed., 51, 588600, 2008b.
Traoré, A., Álvarez, I., Tambourá, H. H., Fernández, I., Kaboré, A., Royo, L. J., Gutiérrez, J. P., Ouédraogo-Sanou, G., Sawadogo, L., and Goyache, F.: Genetic characterisation of Burkina Faso goats using microsatellite polymorphism, Livest. Sci., 123, 322-328, doi:10.1016/j.livsci.2008.11.005, 2009.

Traoré, A., Álvarez, I., Fernández, I., Pérez-Pardal, L., Kaboré, A., Ouédraogo-Sanou, G. M. S., Zaré, Y., Tamboura H. H., Goyache, F.: Ascertaining gene flow patterns in livestock populations of developing countries: a case study in Burkina Faso goat, BMC Genet., 13, 35, doi:10.1186/1471-2156-13-35, 2012.

Traoré, A., Koudandé, D. O., Fernández, I., Soudré, A., Granda, V., Álvarez, I., Diarra, S., Diarra, F., Kaboré, A., Sanoua, M., Tamboura, H. H., and Goyache, F.: Geographical assessment of body measurements and qualitative type traits in West African cattle, Trop. Anim. Health Prod., 47, 1505-1513, doi:10.1007/s11250015-0891-7, 2015.

Yakubu, A., Ogah, D. M., and Idahor, K. O.: Principal component analysis of the morphostructural indices of White Fulani cattle, Trakia J. Sci., 7, 67-73, 2009. 